\title{
Against Dalits Reservation: Exploring the Views of So-Called Upper Caste Students Studying at Kailali Multiple Campus, Dhangadhi
}

\author{
Giri Bahadur Sunar \\ Tribhuvan University Central Deparment of Sociology, Kathmandu, Nepal \\ Email: girithezorba@gmail.com
}

How to cite this paper: Sunar, G. B. (2022) Against Dalits Reservation: Exploring the Views of So-Called Upper Caste Students Studying at Kailali Multiple Campus, Dhangadhi. Sociology Mind, 12, 58-75. https://doi.org/10.4236/sm.2022.122004

Received: January 12, 2022

Accepted: March 6, 2022

Published: March 9, 2022

Copyright (C) 2022 by author(s) and Scientific Research Publishing Inc. This work is licensed under the Creative Commons Attribution International License (CC BY 4.0).

http://creativecommons.org/licenses/by/4.0/

\begin{abstract}
This research article aimed to explore why so-called upper-caste people, predominantly Brahman and Chhetri caste groups, are against 9\% Dalit reservations, though the other five groups have reservations, like 33\% women, $24 \%$ Aadibasi/Janajatis, 20\% Madhesis, 5\% people with disabilities, and $4 \%$ candidates from disadvantaged regions (people from disadvantaged districts in Karnali (basically to Khas Chhetris/Thakuris/Dalits), among others. The reservation has created some antipathy between so-called upper caste people and Dalits. The Supreme Court has also ordered a change in the existing reservation policy from a caste-based to a class-based system. In the midst of ambiguity, applied purposive sampling technique to gain detailed knowledge about a specific phenomenon with so-called upper-caste students studying at Kailai Multiple Campus in Dhangadhi Sub-Metropolitan City. Reservation is an important solution to Dalit prejudice in the present, but it does not solve "past" deprivation of religiously sidelined, socially oppressed, economically exploited, politically oppressed, and educationally deprived people. Compensation is the appropriate solution for the latter kind of discrimination. What more can be done within the current system to ensure Dalits' access to state services if the reservations aren't the solution to their problems?
\end{abstract}

\section{Keywords}

Reservation, Quota, Affirmative Action, Dalit, Upper-Caste

\section{Introduction}

The right to equality was enshrined in Nepal's 2015 Constitution. The third clause of Article 18 said that "The state may not discriminate against citizens based on their ethnicity, religion, race, caste, tribe, sex, economic status, lan- 
guage, area, ideology, or other comparable factors. Nothing in this section shall be construed to impede the legislature from enacting special provisions for citizen protection, empowerment, or development, including socially or culturally backward women, Dalits, indigenous peoples, indigenous nationalities, Madhesi, Tharu, Muslim, oppressed class, Pichhada class, minorities, the marginalized, farmers, laborers, youths, children, senior citizens, gender and sexual minorities, persons with disabilities, pregnant women, incapacitated women."

In 2016-17, the Government took a step toward making the bureaucracy a little less discriminatory, based on the Constitution of Nepal's aspiration; out of $45 \%$ reservation, the most significant amount of new employment in the civil service went to Bahuns (22.96) and Chhetris (18.67) (Public Service Commission, 2019). In 2007, the Civil Service Act of 1993 was revised to ensure that open competition fills $55 \%$ of positions and reserves $45 \%$. Women would receive $33 \%$ of the seats. In comparison, Aadibasi/Janajatis would receive $24 \%$, Madhesis would receive $20 \%$, Dalits would receive $9 \%$, individuals with disabilities would receive 5\%, and candidates from neglected regions (essentially to Khas Chhetris/Thakuris/Dalits) would receive $4 \%$, among others.

Recently, a Supreme Court bench led by Justices Bishwambhar Prasad Shrestha and Ananda Mohan Bhattarai ruled that reservations in government jobs should be based on need rather than caste and ethnicity. They stated that "The constitution can only be achieved if the reservation system is focused on needs rather than on caste or ethnicity." According to justice, reservation did not reach the needy and was occupied mainly by the "Tarmara" (creamy layer) group and opportunist middle-class people. The Supreme Court's decision states that the reservation principle should be under positive discrimination, and the existing system should also be amended. Furthermore, the decision states that a person should not have more than one reservation. With the statement of Justice, debate against reservation began with the notion that caste is replaced by economic grounds for the implementation of quota. While the plan was quickly scorned, by Dalit activist and scholars. The academicians and non-academicians continue to make old and new reasons for reservation policy, ignoring theoretical and empirical issues. The most common critique of the reservation program is that those among the Dalits who are economically better off have benefited more than the weak, and that, as a result, caste should be replaced with economic factors for reservation enforcement.

The Constitution of Nepal has provided "reservation" to secure socio-economic justice to the vulnerable downtrodden sections of the society to bring them to the leading nation's life. For Many centuries, Dalits have been discriminated against; consequently, they are far behind compared to other upper caste people.

According to the data, Dalits have a poverty rate of $41 \%$, which is higher than the national average of 25.16 percent. The Dalits have a literacy rate of $34 \%$, which is lower than the national average of $54 \%$. Their life expectancy is 50.8 years, compared to 59 years for the rest of the country. For fewer than 5 years, the mortality rate is 90 per thousand. The national average is 68 individuals per 
1000. Furthermore, the Dalits have a per capita income of $\$ 977$ per year, which is one of the lowest in the world, compared to the national average of \$1597 per year. Furthermore, $23 \%$ of Dalits are landless, with $48.7 \%$ possessing less than 0.1 hectares of land. Cultivable land is owned by less than $1 \%$ of all landowners. The Dalits in Nepal have the lowest Human Development Index (0.424), much lower than the upper-caste Bahun/Chhetri (0.552), Newar (0.616), and indigenous Janajati (0.494), despite the fact that the national average HDI (0.509) Kharel (2010) and (UNDP, 2009).

Reservation is now being used to entrench caste dominance even further. The reservation will never be able to solve the economic issues of the disadvantaged majority. It is also true that empirically reservation policy in Nepal is benefiting the elite within the Dalit community. Reservation aims are to inject the Dalit people in all state mechanism mechanisms monopoly of the so-called upper caste who are manipulating the state law and order against Dalits. Most of the top-level posts, the police personnel, judges, bureaucrats, and many more are occupied by so-called upper-caste. The reservation can break down the Brahminical ideology of caste superiority that prevented Dalits from commanding respect in society.

According to the United Nations Report 2020, it has been 15 years since the declaration (in 2006, "an untouchable discrimination-free nation") that no human being will be discriminated against based on caste, but caste-based discrimination remains a terrible reality in Nepal. The Caste-Based Discrimination and Untouchability (Offense and Punishment) Act of 2068 prohibits caste-based discrimination and untouchability (2011), which strictly prohibited caste-based discrimination in Nepal. In 2020, the UN had researched Province no.-2, Karnali, and 16 districts in Sudurpachhim province (Province no.-7) and found five different types of harmful practices (caste-based discrimination). According to a report, $97 \%$ of Dalits felt caste-based discrimination in their locality or society. About $74 \%$ of Dalits reported that they are not allowed to enter the kitchen of upper caste people. Similarly, about $52 \%$ of Dalits are not allowed to use water from the public tape, about $50 \%$ of Dalits are not allowed to enter the Hindu temple. However, most Dalits have practiced Hinduism since the beginning; approximately $41 \%$ of Dalits have difficulty selling their milk in the market; approximately $70 \%$ of Dalits do not report cases of caste-based discrimination to the local police station because most upper-caste officers do not want to register Dalits cases. Furthermore, around $67 \%$ of Dalits said that in their society, inter-caste marriage is not possible.

Nepal's Parliament has 8\% Dalit representation. There are 26 Dalit Members of Parliament: 19 in the House of Representatives (out of 275 total) and seven (or 11.8\%) in the National Assembly. In the National Assembly, there are no Dalit women. There are no Dalit women M.P.s who are directly elected (Kalyani, 2020). The Dalit women's representation started after the effects of the Maoist war. To date, to be nominated to a higher political post, Dalits must flatter the 
so-called upper caste party chairperson or prime minister of their affiliated party; once they get a post, it sounds like the job has been done, with no repetition again but for so-called upper caste people, it was repeated time and again. Dalit candidates need to be very loyal (Chamchagiri) to the upper caste party leader or prime minister to get the opportunity. Table 1 shows the detail list of ministers from Dalit community (Pawan, 2021a).

Following the 2017 elections, Dalit representation at the local level improved slightly. Dalits made up 7737 (22\%) of the 35,041 elected legislators throughout 753 local federal entities. The Dalit woman's ward member quota accounted for 6567 (18.7\%) of the 7737 Dalit representatives. Besides the Quota, Dalit members made up only $3.3 \%$ of the total (1170) representatives (Pandeya \& Oyama, 2019). Table 2 shows the details of Dalit Legislative Representation in the three-tier government (Pawan, 2021b).

Quotas helped raise the number of candidates from marginalized communities by a small amount. However, it was hoped that the reservation policy would be maintained, particularly during mass recruitment in the new federal system, making the civil service more representative of Nepal's diverse people.

\section{Research Question}

Reservations were put in place to ensure that historically disadvantaged areas had equal. access to resources. These "reservations" or quotas were granted to Dalits are based on their (presumably immutable) caste identities. The quota system aimed to empower the Dalit community or bring them into the mainstream of development and eradicate long caste-based discrimination. However, the quota system is leading to division and antipathy among Dalits and Non-Dalits community, especially with Brahmin/Chhetri groups. So-called upper-caste Brahmin/Chhetri argues that many Brahmin/Chhetri and others are poorer than Dalits, so they deserve reservation. However, mostly, they are against Dalit reservation.

\section{The Research Aimed to Explore}

1) Why are so-called upper-caste groups, predominantly Brahman and Chhetri groups, against $9 \%$ Dalit reservation?

2) Why are those Brahman and Chhetri groups not against the provided 33\% reservation for women, 24\% for Adivasi/Janajatis, 20\% for Madhesis, 5\% for people with disabilities, and $4 \%$ for candidates from neglected regions?

\section{Literature Review}

Reservation is not absolute, but it is relative. It is not a separate thing but a creation of discrimination for a long time. Critics claimed that reservation or affirmative action is against of merit base system; it promotes casteism but is not reduced; few minutes on the name of minorities gained an opportunity (Deshpandey, 2013: p. 20). According to Marc Galanter, the justification behind the 
Table 1. List of ministers representing dalit community.

SN. Name Position $\quad$ Party

1. Hiralal Bishwakarma

2. Parkash Chitrakar

3. Lal bahadur Bishwakarma

4. Harishankar Pariyar

5. Golche Sharki

6. Partaparam Lohar

7. Manbahdur Bishwakarma

8. Khadak bahadur Bishwakarma

9. Chhabilal Bishwakarma

10. Mahendra Paswan

11. Nabin Kumar Bishwakarma

12. Jitu Gautam (Darji)

13. Khadak Bahadur Basel

14. Kalawati Paswan

15. Dal Bahadur Sunar

16. Gopi Achami

17. Ramani Ram

18. Bisbindra Paswan

19. Daljit Sripaili

20. Dhanmaya BK.

21. Minbahadur Bishwakarma

22. Jagat Bishwakarma

23. Bimala Bishwakarma

24. Asha Bishwakarma

25. Maheshwar Gahatraj
Assistant Minister of Education-1975 (2032), Minister of State for Supplies-1984 (2041)

Assistant Ministry for Land Reforms and Management-2002

(2051), 2005 (2062)

Assistant Minister for Population and Environment-2004 (2061)

Assistant Minister for Physical Planning and Construction-2004

(2061), Assistant Minister of Forest and Land Conservation-2005 (2062)

Physical Infrastructure and construction Assistant Minister-2005

(2062), Assistant Minister of Women and Children-2005 (2062)

Assistant Minister for Environment and Technology-2005 (2062) King

Minister of State for Environmental Science and Technology-2006 (2063)

Minister of Women and Children-2006 (2063), Tourism Civil

Aviation-2010 (2067)

Minister for Agriculture and Cooperatives-2006 (2063)

Minister for Land Reforms and Management-2007 (2064),

Minister for Industry-2010 (2067)

Minister of State for Local Development-2008 (2065)

Minister of State for General Administration-2008 (065)

Assistant Minister for Health and Population-2009 (2066)

Minister of State for Physical Infrastructure and

Construction-2009 (2066)

Minister of State for Irrigation-2010 (2067)

Minister of State for Youth and Sport-2011 (2068)

Minister of State for Irrigation-2011 (2068)

Minister for Environment and Science-2015 (2072)

Minister for Youth and Sport-2016 (2073)

Non- departmental Minister-2016 (2073)

Minister of Commerce-2017 (2074)

Minister of Youth and Sport-2017 (2074)

Minister of State for Industry and Commerce-2021 (2078)

Minister of State for Forests and Environment-2021 (2078)

Ministry of Youth and Sport-2021 (2078)
Panchayet

King

UML

Congress/King

King

Congress

Maoist

UML

Maoist

Maoist

UML

Congress

MJF

UML

Maoists

TAMALOPA

Bahujan Shakti party

Maoists Kendra

Maoists Kendra

Congress

UML

UML

MALE

Maoists 
Table 2. List of Dalit legislative representation in the three-tier government.

\begin{tabular}{|c|c|c|c|c|}
\hline Position & Total No. & Dalit representation & Percent & Need for the number as per population \\
\hline Member of the House Representatives & 275 & 19 & 7 & 38 \\
\hline Member of the National Assembly & 59 & 7 & 12 & 8 \\
\hline Member of State Assembly & 550 & 33 & 6 & 76 \\
\hline Mayor & 293 & 6 & 2.04 & 40 \\
\hline Deputy Mayor & 293 & 11 & 2.75 & 27 \\
\hline District Coordinating Committee President & 77 & 9 & 11.68 & 11 \\
\hline District Coordinating Committee Member & 534 & 99 & 18.53 & 74 \\
\hline Village Municipality President & 460 & 1 & 0.21 & 63 \\
\hline Village Municipality Vice-President & 460 & 16 & 3.47 & 63 \\
\hline Ward Vice-Chairman & 6743 & 197 & 2.92 & 930 \\
\hline Municipal Executive Member & 6287 & 855 & 13.59 & 867 \\
\hline Village Municipality Member & 6789 & 1078 & 15.98 & 936 \\
\hline Dalit Women Members & 6743 & 6567 & 97.39 & \\
\hline Ward Members & 13,486 & 797 & 5.90 & 1861 \\
\hline
\end{tabular}

reservation policy is that the historically disadvantaged population should be provided with preferential treatment. He argues: "Preferences are of three basic types: First, there are reservations, which allow or facilitate access to valued positions or resources. Reserved seats in legislatures, reserving roles in government service, and spaces in academic institutions are the most prominent examples of this category (especially in the coveted higher technical and professional colleges). To a lesser extent, the reservation device is also used to distribute land allotments, housing, and other scarce resources. Second, there are programs involving expenditure or provision of services, e.g, scholarships, grants, loans, land allotments, health care, legal aid, to a beneficiary group beyond comparable expenditure for others. Third, there are special protections. These redistributive plans are supported with attempts to safeguard the poor from being exploited and mistreated. Forced labor is illegal under the Constitution, and there have been concerted efforts in recent years to free debt bondage victims, who are largely from designated castes and tribes" (Louis, 2003). Bhimrao Ambedkar proposed a mix of four or more remedies to promote equal opportunity, fair access, and involvement of marginalized groups in society's social, political, and economic processes. Equal rights, legal safeguards against rights violations in the form of punitive measures, measures to ensure equal access and participation through reservation policies in the civil, political, and economic spheres, and a solid-state strategy for the development and empowerment of marginalized people to compensate for past exclusion (Thorat \& Negi, 2005, pp. 16-22, cited by Pyakurel, 2011).

By contrast, the anti-reservationists view reservations as antithetical to the 
idea of equality of opportunity. They argue that individual merit is ignored in the name of social justice, which results in injustice to the meritorious. This leads to frustration among them and hence affects social efficiency. Secondly, they say that reservation sharpens caste boundaries instead of breaking them. Thirdly, they find collectivity as a basis for compensatory discrimination to be anti-individualistic. They wish to scrap the reservation as they have been in operation for a long time (Desai \& Desai, 1990). Ramachandra (1982) studied the elite's attitude toward the reservation policy in Karim Nagar district (Andhra Pradesh). He found that the elites belonging to the dominant castes were strongly against the reservation policy and most of them were in favor of the termination of the reservation policy. They considered the policy of reservations in government employment as "ruinous". By contrast, most of the scheduled castes favored the continuation of the reservation policy in government employment.

Since the early 1960s, when President John F. Kennedy of the United States used the term "affirmative action" to describe public policies intended "to overcome the current effect of past racial discrimination" in executive-order no. 10925 (assigned to the secretary of labor the task of specifying rules and implementation), it has been used to describe public policies intended "to overcome the present effect of past racial discrimination" (Louis, 2005). The terms "preferential treatment", "reverse discrimination", "positive discrimination", and so on are all used to refer to comparable affirmative action provisions. It is a legal framework where the law imposes special measures or differential treatment for various individuals or groups. The basis for a provision is that a specific condition should exist that demands such special measures departing from the principle of formal equality. Therefore, affirmative action aims to protect or promote the welfare of a person or a group who/which was previously marginalized, suppressed, or discriminated (Lerner, 2003). Affirmative action is a by-product of the civil-rights Movement in numerous ways. IN PARTICULAR, Title VII of the 1964 Civil Rights Act barred discrimination in the workplace based on race, color, creed, or sex (Schmidt Jr., 1965). Affirmative action is coming under increasing fire.

Some say that racism is no longer a problem, that restitution for past wrongs is inappropriate, and that a race-based policy cannot achieve the ultimate aim of a color-blind society. Others acknowledge the need for affirmative action but argue for a broader definition of disadvantage, focusing on socioeconomic status factors other than race or ethnicity. According to this viewpoint, "class-based" affirmative action is more equitable and politically acceptable to achieve identical goals. In the wake of recent court judgments suggesting that race-based scholarship admission programs may be illegal, proposals for class-based affirmative-action measures have become particularly prominent in college admissions. Several schools, notably the University of California system, have moved to phase out race and ethnicity-focused programs in favor of those based on alternate conceptions of disadvantage (Cancian, 1998). 
In the 1890s, under British colonial power, affirmative action policies were initially applied in India to compensate for the exclusion of lower caste and Dalit (outcaste) groups from employment and educational institutions. India has far and by the most recent experience with such measures, and it gives fascinating examples of their benefits and faults. Similar methods were devised in the United States in the 1970s in response to perceived shortcomings in the mid-1960s Civil Rights Act. Following the bloody ethnic riots between Malays and Chinese in 1969, Malaysia adopted affirmative action; Sri Lanka used the strategy during the post-independence Sinhalese-Tamil tensions, and South Africa used the strategy to address some of the gross inequalities between Hites and Africans after apartheid ended in the early 1990s (Stone \& Dennis, 2003). This comprehensive formula was suggested by Ambedkar after he realized the limitation of antidiscrimination laws (Rodrigues, 2002: p. 33), reservation and affirmative action, and so on. He, then, put special responsibility on the state, saying that "the uplift of the Depressed Classes will remain a pious hope unless the task is placed in the forefront of all governmental activities". Also, he puts forward his doubt about the implementation of laws and other pro discriminated policies "unless equalization of opportunities is realized in practice by a definite policy and determined efforts on the part of the government". Generally, Affirmative action or reservation is seen as a mechanism to do away with socioeconomic, political, and cultural inequalities. Nepali society is hierarchical, generating inequalities and passing from one generation to another. This has led to severe social, psychological, educational, and economic deprivations among the Dalit community and has caused irreparable harm. Thus, to bring them at par with the privileged groups, they should be allowed specific compensation, and reservations must be the primary compensatory measure for their social mobility.

\section{Method}

So-called upper-caste respondents' attitudes to the reservation and its implementation were also sought. They were questioned why some so-called upper-caste groups, predominantly Brahman and Chhetri groups, are against 9\% Dalit reservation? Why are those Brahman and Chhetri groups not against the provided 33\% reservation for women, 24\% for Aadibasi/Janajatis, $20 \%$ for Madhesis, $5 \%$ for people with disabilities, and $4 \%$ for candidates from neglected regions?

Being a Dalit interviewer, I did not take the interview because the respondent might know me personally, and to be nice to me, respondents may reply in my favor. So, I took the support of a qualified and experience upper-caste interviewer, applied purposive sampling techniques to gain detailed knowledge about a specific phenomenon with so-called upper-caste students studying at Kailai Multiple Campus in Dhangadhi Sub-Metropolitan City. This paper had also analyzed secondary data, policy documents, empirical data published in Public Service Commission Report: 2020/21, and other national and international 
documents. Aside from that, I use Gopal Guru's theory of lived experience, which claims that Dalit lived experience is the only legitimate and authentic experience and that theorizing this experience should be limited to Dalits. You cannot have a Dalit experience unless you are a Dalit yourself, or at the very least know what it is like to be a Dalit subject with no choice. As a result, participatory observation would not be considered lived experience as long as the observer, who may ordinarily live in and enjoy the community, has the option to leave when things get bad or when the observer chooses to leave, but the Dalit subject is oppressed with no way to escape this oppression (Guru, 2002). Levinas' theory of the Holocaust is also based on personal experience, specifically a personal experience of Nazism that he and his family had to undergo. His development of an ethical theory is directly mediated by a lived experience, not only by experience (Sarukkai, 2007).

\section{Main Findings and Discussion}

Despite qualified upper-caste interviewer's engagement, it became difficult to get the proper answer from the students on their biased nature toward Dalit reservation. Most of the respondents were students who have had little knowledge behind the main moto of reservation. Without proper understanding of reservation, students were found debating on Dalit reservation matters. Among the respondent, about $63.7 \%$ respondents opined that the reservation should be based on class, and only $36.3 \%$ wanted the reservation to be based on caste. Among the respondents, some had a good understanding of the reservation system, and they were found positive about it. According to the optimistic respondents, reservations for Dalits should be based on caste, not on class. Another group, those who wanted reservations based on economic position (class) criteria, argued that the reservations based on caste create and intensify social barriers and lead to stigmatized identity. Most of the respondents, however, were from an urban background.

To make it further clear why caste-based reservation is needed instead of class-based, I want to give an example of a Brahmin and Dalit family residing in the same village, environment, and economic status. After noting their low financial situation, a benefactor had gifted both households with a similar number of milk-giving buffalo. Now you have to estimate which of the two families will improve their financial situation in a short period and why (It's safe to presume that readers are familiar with the Hindu caste system, as well as its social and religious structure). The answer is straightforward; the poor Brahmin family will become economically stronger in a short period in comparison to the Dalit family because of caste privilege and social capital of Brahmin family, while Dalit family will not enhance economic condition that fast because upper caste people will not buy milk brought by Dalit family and Dalit family touched have no better social capital and no caste privilege in the market. Due to caste identity, Dalits are not able to sell their editable products or start restaurant businesses in their own locality. If they know his or her caste identity, no upper-caste person 
will eat or buy a Dalit product. The social arrangement is so discriminatory against Dalits that they cannot sell their editable products on the market. The reservation policy intends to make Dalits capable. The key idea of the capability approach is to expand people's capabilities, their freedom to promote or achieve valuable beings and doings as an essential path to progress, development, or poverty reduction. People have greater freedom of functioning (Sen, 1999). The Dalits suffered discrimination in a variety of marketplaces, including employment, the provision of inputs and services (necessary for farm and non-farm production), and the selling of products by the erstwhile Dalits to farmers and non-farm producers/businesspersons. In local places, Dalits are not employed for certain jobs, such as chefs in restaurants and in the mid-day meal program for children, or waiters. The caste system is a social structure, while the class structure is a financial structure. In the market, the upper Caste has advantages over the lower Caste. The caste system is a social system, while the class system is a financial system. The upper caste gets privilege in the market while the lower caste does not. Those respondents who favor reservation based on social position (Caste) argued that the Dalits are economically backward and socially and educationally deprived. Whereas upper caste people, especially Brahmins, are not socially and educationally backward even though poor, they still occupy a superior position in the hierarchy. If they are poor, they are just economically deprived, not ritually and socially.

In Nepal, castes/ethnic groups are reported in the census 2011. Even if we support the class type of reservation, the Dalit community will get more opportunities because about $41 \%$ of the Dalit population are poor below the poverty line. The population of Dalit is $13.6 \%$, while the population of Brahman is $12.2 \%$ as per the census of 2011. Chhetri is the largest caste/ethnic groups having $16.6 \%$ $(4,398,053)$ of the total population followed by Brahman-Hill $(12.2 \% ; 3,226,903)$, Magar (7.1\%; 1,887,733), Tharu (6.6\%; 1,737,470), Tamang (5.8\%; 1,539,830), Newar (5\%; 1,321,933), Kami (4.8\%; 1,258,554), Muslim (4.4\%; 1,164,255), Yadav $(4 \% ; 1,054,458)$ and Rai $(2.3 \% ; 620,004)$. There must be a clear understanding of reservation. Reservation for Dalit is not secured because of their poverty status. Dalits' reservation or quota system is provided because of aged long caste-based discrimination. Caste-based discrimination is not only a matter of economics; it is social and political. Dalit poverty is a result of long-term social isolation. As a result, reservation is for social inclusion, civil service, judiciary, military forces, and politics. It is also true that caste discrimination will persist regardless of how far Dalits advance economically. Dalit is a social and political issue, not just an economic one. Even though reservation has been in place for nearly two decades, Dalit representation remains a shambles. Dalits and women are not adequately represented in Nepal's courts and other state institutions. Only seven Dalits (1.3\%) among the 519 public prosecutors. At the Supreme, High, and District Court Levels in 2017-18, there were 394 judges. There were just 14 female judges in these courts, accounting for only $3.5 \%$ of all judges. Only $0.5 \%$ of judges were Dalits. One Dalit judge and a Dalit woman were recently 
appointed to the High Court and the District Court, respectively. In the Supreme Court, there are no Dalit justices (Kalyani, 2020). Out of 459 judges, five (1.09\%) represent the Dalit minority, according to the Public Service Commission's 60th annual report. In the civil service, Dalits make up $0.64 \%$ of the population, while Bahuns make up $72.00 \%$ of the population (12.74), Chhetris make up 15.89 percent of the population (15.80), Newar Janajati makes up 7.14\% of the population (5.48), non-Newar Janajati makes up $1.64 \%$ of the population (30.83), Madhesis make up $1.17 \%$ of the population (12.32), Muslims make up $0.1 \%$ of the (Prasai, 2017). According to the Public Service Commission's 60th annual report, out of 88,578 civil servants, there are 1971 (2.22\%) Dalits who are working. Recently, Man Bahadur BK was promoted and became the government secretary of Nepal. Mr. BK has been the first Dalit to reach the particular class (the rank of secretary) in the country's civil service. Out of 65,500 Police personnel, there are 6192 (9.45\%) Police personnel who is represented by the Dalit community; similarly, out of 87,972 armies, there are $7164(8.14 \%)$ armies who are represented from Dalit Community (Public Service Commissions, 2019).

It is also true that few Dalits are availing the benefits of protective discrimination and most of the Dalit community who are from poor and rural backgrounds are not able to avail themselves of the benefits as most of the seats are taken over by the children of elite Dalits from an urban background. If the father or mother is in a good position (e.g., politician, ministers, doctor, lecturer, police officer, army officer, bureaucratic officers), he or she should not avail reservation for his/her children as they might have studied in good schools but the Dalit students from a poor socioeconomic rural background, with not so good educational background, cannot compete with the privileged few. They reach parents must leave the space for the poor rural Dalits; reservation must be secured for most needy Dalits, and exceptional facilities and help should be given to poor children of all castes (even upper castes), the child of poor parents may not have the money to buy school textbooks. He should, therefore, be provided the textbooks free of charge by the state.

In response to "why some so-called upper-caste groups, especially Brahman and Chhetri groups are against the 9\% Dalit reservation system? Why those Brahman and Chhetri groups are not against the provided 33 percent reservation for women, 24 percent for Aadibasi/Janajatis, 20 percent for Madhesis, 5 percent for people with disability, and 4 percent for candidates from neglected regions?".

Among the respondent, about $70 \%$, had responded that they are against Dalit reservation because whenever caste discrimination is raised, Dalits only blame Brahmin and Chhetri caste groups. Dalit thinks that Brahman and Chhetri are the all-cause of trouble and discrimination, so Brahman and Chhetri are against Dalit reservation. According to Brahmin and Chhetri respondents, reservation is extending enmity between Brahman/Chhetri and Dalit groups. So, reservation must not give to Dalits; Dalits must compete with Upper caste people. It should be given based on class if the reservation is given, not caste. I did not get rea- 
sonable and academic response for the asked question.

In response to a similar question, Nobel laureate economist Becker stated that white males discriminate against their black counterparts because they have a discrimination test from which they derive utility, and this test is based on prejudices that an individual from one group holds against individuals from another group, in this case, blacks and women (Becker, 1956, cited by Thorat, Tagade, \& Naik, 2016).

In 1973, another Nobel laureate, Arrow, proposed an alternative reason for discrimination: people discriminate because they believe that people from another group are, on average, less productive, and as a result, they make hiring and wage decisions for other group members based on that belief, which may be incorrect and result in discrimination (Akerlof \& Kranton, 2010 cited by Thorat, Tagade, \& Naik, 2016). Individual decisions are socially framed, according to the "identity theory" and social categories and their norms affect how individuals in the social category act toward others. When it comes to race and poverty, the Identity theory suggests that whites' attitudes about blacks are shaped by group norms that maintain a divide between "us" and "them". Instead of seeing black people as "us all" white people see them as "them". Discrimination occurs from this divide of standards based on "us" and "them", or what writers refer to as “oppositional identity” (Tajfel \& Turner, 2004). Prejudice stems mostly from an individual's psychological makeup. The psychology of prejudice, which results in the dominant group's stereotyped (false) views and discriminatory conduct toward the inferior group, is comparable to the Test theory (Allport, 1954). The contends that "race prejudice exists in sense of group status rather than in a collection of individual sentiments which members of one racial group experience toward members of another racial group", challenging Allport's theoretical construct of prejudice as a set of individual feelings. In order to sustain a relative group interest, Blumer changes the axis of bias away from individual impulses and toward communal interests. For monetary gain and high social prestige, the emphasis is on group position and collective efforts (rather than individual efforts) (Blumer, 1958 cited by Thorat, Tagade, \& Naik, 2016).

This vested interest continues to push them to practice discrimination in different domains since discrimination acts as a tool for economic benefits and high social standing for the higher castes. As a result, comprehensive policies for both market and non-market institutions, as well as all other sectors where prejudice exists, must be implemented.

The case of Rupa Sunar and Sarawati Pradhan of Babarmahal, Kathmandu, also proved that some so-called upper caste people are against Dalit reservation. The news that a house owner, Sarawati Pradhan, is refusing to rent an apartment to a Dalit journalist, Rupa Sunar, due to her Caste, has sparked public outrage after she posted a video about it on the Internet. Sunar also filed a case with the Nepal Police Department under the Caste-based Discrimination and Untouchability (Offense and Punishment) Act, 2011, but Pradhan was released owing to 
political pressure from a sitting minister, Krishna Gopal Shrestha (Regmi, 2021). A minister's involvement in a high-profile caste discrimination case raises questions of state complacency. With this incident, few upper-caste people started to post their status on social media, stating that "timile kotha payenau, maile Quota paina." (You did not get a rented flat; I did not get Quota). Such status proved how some so-called upper-caste people are against providing reservations for the Dalit community. They had intentionally compared the two words "flat" and "quota" to humiliate Dalits. The issue of flat and Quota is quite different.

Social exclusion and discrimination are a "group idea" based on group identities such as race, color, religion, ethnicity, caste, and gender. In the situation of group exclusion, all members of a group are excluded because of their social identity, regardless of their economic status within the group, rendering the discrimination economically neutral. Dalits experience prejudice based on their caste identification, regardless of their financial condition, because individuals from higher castes do not distinguish between economically poor and well-off. As a result, anti-discrimination rules such as reservations are based on a group's social identity rather than an individual's economic status. It's hardly unexpected that a number of nations have paired anti-poverty efforts with equal opportunity legislation for marginalized groups based on group identification. The inability of detractors to recognize this distinction has resulted in widespread misunderstanding, as the case for replacing caste with economic factors for reservation is built on shaky theoretical ground (Thorat, Tagade, \& Naik, 2016).

After completing the school level certificate and examination from Amar Higher Secondary School, Bihunkot, now Kathekhola Rural Municipality-5, Baglung, I entered the Mahendra Multiple Campus in Baglung for further study. I had rented a room for further study at the house of the Newar family in Baglung Bazar. The family had a mentally disturbed father, mother, and son. The son was a strong supporter of the communist party. I did not hide my Caste while renting a room. The half-month of staying was excellent and smooth, suddenly one day, the father of the Newar family disappeared. I, including the son of the mentally disturbed father, searched him around the jungle, mountain, river, and market; about 23 days later, the father of the Newar family was found dead. At that time, my proficiency level examination was about to start, and I had dedicated most of my productive time in search of the house owner's mentally disturbed father. The very evening when a dead body was found, I was out of the rented room to combine study with my classmates, it was a little bit late when I arrived home. When I arrived, I saw house owner's house was filled with their family members and relatives to conduct 13 days of death rituals (Kriya-Karma). Immediately after I entered the home, the son-in-law of the family asked me to leave my rented room because the lowly born Caste (Dalit) was not supposed to stay in an upper-caste home when someone died in their family. I was shocked; my exam was about to start from next day, it was already late evening and raining outside. I was confused about how an educated son-in-law asked me to leave the room. I had tremendous respect for his master's level education in sociology and affilia- 
tion with the Maoist Communist Party. I had no option; I packed all my stuff in the late evening and sifted nearby clothes store. That night, I could not sleep because I was awake; my eyes were raining like it was raining outside. I went to the next day's exam with a fatigued and troubled head, but I did not do well; the result was poor (Sunar, 2021). With this lived experience, do you still think that a Dalit student could compete with upper-caste students who had no such experience and suffering? A story of mine cannot be generalized, but there are many Dalit students are residing in rented rooms in the capital city and district headquarters and around for further study; some had dared dare to share their real caste identity, and some did not in fear of not getting room and fear of stigmatization. This way or that way, Dalits are suffering. It is the lived experience of the 21 st century; such kind of discrimination is going on. Since this age, Dalits have been psychologically paralyzed and stigmatized. Likewise, Angira Pasi, a 12-year-old Dalit girl, was discovered hanging from a tree on May 23, 2020, a day after community leaders in Rupandehi district ordered a 25-year-old man of a different caste had raped her to marry her as "punishment".

Six men were killed in the Rukum West district on the same day as a young Dalit guy arrived to marry his non-Dalit girlfriend. According to media sources, both cases involved allegations against elected local government officials (Human Right Watch, 2020). Honor killings and other caste-based crimes, such as untouchability, remain a source of prejudice. For Dalits, discrimination is a reality; others may sympathize with their cause, but they cannot comprehend what they are going through. The law or legal bodies have not addressed this issue.

A huge misunderstanding is found among upper-caste; Dalits are raising their voice against caste-based discrimination, Dalits are expressing their pain and suffocation, but so-called upper-caste Brahmin and Chhetri groups perceive Dalit's voice as blaming or scolding them. This misunderstanding creates a kind of enmity between upper-caste and lower-caste people. This is seen in their bias against reservation for Dalits.

As a researcher, I also understand the pain and complain of so called-upper caste highly qualified students who might be economically poor and not selected for the desired post because of their upper-caste castle status. Here, I want to clear that out of a hundred percent available seats, only $45 \%$ of seat is reserved, and $55 \%$ of the seat is available for open competition, so no need to blame or scold or humiliate the Dalit community. It will not also be good to blame that Dalit who is not so intelligent with average marks get admission or employment were sometimes a sound and the intelligent the upper-caste student does not get these seats. Dalits are competing within Dalit reserved seats seat and selection is made after a competition among qualified Dalits, so the question of average marks and unintelligent is pathetic. It is not good to say the reservation system is not fair and that there should not be any reservation based on caste. Those who are against reservation must look back to their history where Dalits were not allowed to educate themselves, Dalits were not allowed to get into the temple, Dalits were not allowed to listen and read Hindu religious scriptures, Dalits were 
not allowed to put on good clothes and ornaments even though they prepared it, Dalits were not allowed to participate in a social gathering, not inter-caste dining, no inter-caste marriage, and many more, so-called upper caste were allowed to educate themselves and many more. In the past, so-called upper-caste people enjoyed direct reservation but not Dalits.

The reservation is not supposed to widen the gap between upper-caste and lower-caste (Dalits); those who think it will widen the gap are against Dalit upliftment and bias. Some Dalits are as intelligent as upper-caste people, even better than upper caste people, and they are equally capable of doing competition with upper-caste people without any reservation and securing the desired post on the based merit or capacity, but still, upper-caste bias mind thinks that Dalits got the desired post through a Quota system. The reservation is for social inclusion or to create a just and equal society where every human being can live with high moral and social dignity.

\section{Summary}

Pin-pointing only Dalits among the other five categories of the reservation is unfair. Reservation does not imply that qualifications and selection procedures are no longer required. A reduction of minimum educational qualifications, short-listing standards, screening tests, and interviews for Dalits in the $9 \%$ protected seats cannot be interpreted as an exemption from minimum educational qualifications. Without any empirical proof, the so-called upper-caste creates an illusion that the entire $13.6 \%$ of Dalits benefit from the reservation. In reality, there are few; the above- illustrated data from Public Service Commission is absolute proof for justification. Dalits suffered historically, and reservation is a process to bring them into the mainstream of development. The issue of Dalits is social, economic and political; Dalits are seeking equal dignity and respect in the existing society. So, reservation aimed to enrich Dalit's dignity and social status. Academic parlance of the reservation is to equal distribution of primary goods like wealth, prestige, power, rights, honors, self-respect, dignity, duties, gains, and burdens in society. The poor social and economic status of Dalit is the by-product of aged long caste-based discrimination. So, reservations should be based on caste not based on class. The political parties should make caste and equity their prime agenda. They can do so by appealing to equality in the Constitution. Reservation is an important solution to Dalit prejudice in the present, but it does not solve "past" deprivation of religiously sidelined, socially oppressed, economically exploited, politically oppressed, and educationally deprived people. For the latter type of discrimination, compensation is the appropriate remedy. Rather than being anti-Dalit, reserved upper-caste members must be trained to stop discriminatory and painful actions against Dalits, only then would it do away with the need for a reservation.

\section{Conclusion}

Dalits experience prejudice based on their caste identification, regardless of their 
financial condition, because individuals from higher castes do not distinguish between economically poor and well-off Dalit. The so-called upper-caste people discriminate against Dalits. The inability of detractors to recognize this distinction has resulted in widespread misunderstanding, as the case for replacing caste with economic factors for reservation is built on shaky theoretical ground. The Supreme Court judges' decision against reservation sounded like they had declared the "Communist Manifesto". The Supreme Court is for Class-based reservation instead of "Caste". The Supreme Court's decision makes doubt on their academic understanding of differences between "Cast" and Class, or intentionally they ignored the issues of Dalit and wanted to continue the same so-called upper caste monopoly in all state structures. It has been only 15 years of reservation system in Nepal, How the "Tarmara" Creamy layer group was born within 15 years. The neighboring country, India is practicing a reservation system for the last 70 years. Still, not more than $5 \%$ of Dalits can enter the middle class. It is also understandable that those economically sound Dalits must not seek reservation; those who reach Dalits must leave seats for the poor and powerless. The court also mentioned that class-based reservation should be provided only for one time for a person; if so, then a person who enters the Nepalese bureaucracy through reservation in the post of the clerk or will not be able to be promoted to the post of secretary or other senior decision-making position because one-time reservation will not allow him or her to take part in another level or reservation opportunity. If Dalits were stopped with a one-time reservation opportunity, there would be no Dalits in decision-making. The so-called upper caste people possess the whole state structure, and being against reservation is their prejudice. If the reservation is not the answer to the Dalit problem, what else can be done within the existing systems to secure Dalit inclusion in state services? What should the parameters of a class-based reservation be if reservations should be based on class rather than caste?

\section{Conflicts of Interest}

The author declares no conflicts of interest regarding the publication of this paper.

\section{References}

Akerlof, G., \& Kranton, R. (2010). Identity Economics: How Our Identities Shaped Our Work, Wages and Well-Being. Princeton University Press. https://doi.org/10.1515/9781400834181

Allport, G. (1954). The Nature of Prejudice, Addison. Wesley Publishing Company.

Becker, G. (1956). The Economics of Discrimination. University of Chicago Press.

Blumer, H. (1958). Race Prejudice as a Sense of Group Position. Pacific Sociological Review, 1, 3-7. https://doi.org/10.2307/1388607

Cancian, M. (1998). Race-Based versus Class-Based Affirmative Action in College Admissions. Journal of Policy Analysis and Management, 17, 94-105. https://doi.org/10.1002/(SICI)1520-6688(199824)17:1<94::AID-PAM6>3.0.CO;2-A 
https://www.jstor.org/stable/3325867

Desai, M., \& Desai, A. R. (1990). Justification of Reservation for OBCs: A Critique of Shourie and Others. CG Shah Memorial Trust Publication.

Deshpandey, A. (2013). Asamanta ra sakaratmak kadam: Jatiyavedvab ra banchitikaran ilaz thanieka sakaratmak kadamko lekhajokha. Himal Kitab Private Limited.

Guru, G. (2002). How Egalitarian Are the Social Sciences in India? EPW, 27, 5003-5008.

Human Right Watch (2020). Nepal: Ensure Justice for Caste-Based Killings. https://www.hrw.org/news/2020/06/01/nepal-ensure-justice-caste-based-killings

Kalyani, S. P. (2020). What Is Similar between Indian and Nepal? Dalit Atrocities. https://www.newsclick.in/What-is-Similar-Between-India-and-Nepal-Dalit-Atrocities

Kharel, S. (2010). The Dialectics of Identity and Resistance among Dalits in Nepal. Doctoral Dissertation, The University of Pittsburgh.

Lerner, N. (2003). Group Rights and Discrimination in International Law (Vol. 77). MartinusNijhoff Publishers.

Louis, P. (2003). Scheduled Castes and Tribes: The Reservation Debate. Economic and Political Weekly, 38, 2475-2478. http://www.jstor.org/stable/4413699

Louis, P. (2005). Affirmative Action in Private Sectors: Need for a Nation Debate. In A. Sukhadeo Thorat, \& P. Negi (Eds.), Reservation and Private Sector: Quest for Equal Opportunity and Growth (p. 14). Rawat.

Pandeya, G. P., \& Oyama, T. (2019). The Question of Equal Representation of Citizens in the Legislature of Nepal: Rhetoric and Reality. Asian Journal of Political Science, 27, 45-69. https://doi.org/10.1080/02185377.2019.1570471

Pawan, B. (2021a). Aarakchhanmathi Aakros Aati, Tara Dalitlae Awashar Naganya. https://www.nayapatrikadaily.com/news-details/66265/2021-06-28

Pawan, B. (2021b). Janhapaila-Pailama Jatiya Bibhed Chha. https://www.nayapatrikadaily.com/news-details/66375/2021-06-30?fbclid=IwAR2ajbD AA6wdK0rdP27MOFFSO0y4Zbcz2sKjzjKewJavtke5EgsZ1hDx7vU

Prasai, D. R. (2017). Issues of Reservation and Affirmative Action for Minorities in Nepal: An Anthropological Review. Himalayan Journal of Sociology and Anthropology, 7, 1-12. https://doi.org/10.3126/hjsa.v7i0.17148

Public Service Commission (2019). 60th Annual Report. Anamnagar, Kathmandu.

Pyakurel, U. (2011). A Debate on Dalits and Affirmative Action in Nepal. https://www.epw.in/journal/2011/40/special-articles/debate-dalits-and-affirmative-acti on-nepal.html

Ramachandra, M. (1982). Group Attitudes towards Reservation Policy. In B. A. V. Sharma, \& K. M. Reddy (Eds.), Reservation Policy in India. Light \& Life Publishers.

Regmi, U. (2021). Rupa Sunar-Saraswati Pradhan Controversy: What Does the Law in Nepal Say?

https://english.onlinekhabar.com/rupa-sunar-saraswati-pradhan-controversy-what-do es-the-law-say.html

Rodrigues, V. (2002). The Essential Writing of B. R. Ambedkar.

Sarukkai, S. (2007). Dalit Experience and Theory. Economic and Political Weekly, 42, 4043-4048.

Schmidt Jr., C. T. (1965). Title VII: Coverage and Comments. B.C. Indus. \& Com. Law Review, 7, 459.

Sen, A. K. (1999). Development as Freedom. Knopf Press. 
Stone, J., \& Dennis, R. (2003). Race and Ethnicity: Comparative and Theoretical Approaches. Blackwell Publishing.

Sunar, G. B. (2021). Bibhed Kunae Jat Samudayale Haina, Byaktile Garchha. https://www.setopati.com/search?from=\&search_text=\%E0\%A4\%97\%E0\%A4\%BF\%E0 \%A4\%B0\%E0\%A5\%80\%E0\%A4\%AC\%E0\%A4\%B9\%E0\%A4\%BE\%E0\%A4\%A6\%E0\% A5\%81\%E0\%A4\%B0+\%E0\%A4\%B8\%E0\%A5\%81\%E0\%A4\%A8\%E0\%A4\%BE\%E0\%A $\underline{4 \% \mathrm{~B} 0}$

Tajfel, H., \& Turner, J. C. (2004). The Social Identity Theory of Intergroup Behavior. In Political Psychology (pp. 276-293). Psychology Press. https://doi.org/10.4324/9780203505984-16

Thorat, S., \& Negi, P. (2005). Reservation and Private Sector: Quest for Equal Opportunity and Growth. Rawat.

Thorat, S., Tagade, N., \& Naik, A. K. (2016). Prejudice against Reservation Policies: How and Why? Economic and Political Weekly, 61-69.

United Nations Development Programme (UNDP) (2009). Nepal Human Development Report 2009: State Transformation and Human Development. United Nations Development Program. 